\title{
The European Union Budget, the Balanced Budget Rule and the Development of
}

\section{Common European Policies}

\section{Abstract}

The European Union budget is subject to a strict annual balanced budget rule. Given different types of expenditure within the budget, this rule has most effect on - and is most threatened by - spending on the Common Agricultural Policy. This article examines the merits of applying a balanced budget rule to the EU budget and explores the links between the budget and the CAP. The presence of the rule also forced the EU to improve its financial management. The 1999 CAP reform is examined. The presence of a pre-agreed spending limit on the CAP forced changes to be made to the initial CAP reform agreement in order to comply with this limit, although political bargaining was critical in shaping the changes. The general perception is that the CAP drives the European budget. The budget, if not driving the CAP, imposes an increasingly tight constraint on its reform. 


\section{Introduction}

In several key respects the central budget of the European Union (hereinafter, the EUB) is quite different from member state governments' national budgets, notably that it is much smaller than national budgets and that it must be in balance each year. There are also different types of expenditure, differentiated by which European institution has ultimate control over their determination. The purpose of this paper is to assess the role of the balanced-budget rule as it applies to the EUB. It argues that this rule has had the greatest relevance for and impact on agricultural support expenditures and has ultimately been crucial in driving agricultural policy reforms through the 1980s and 1990s. It is also argued the balanced budget rule has been central to EU reforms improving the financial management of the EUB.

The paper starts by outlining some key features of the EUB. It then explores the issue of the balanced budget rule, considering the suitability of the EUB for the application of this rule. Section 4 identifies some concerns over the application of this rule and examines the relevance of these concerns to the EUB. Section 5 then focuses on the role of reforms to the Common Agricultural Policy in supporting EU fiscal restraint. In Section 6 this argument is taken one step further, by arguing that the 1999 CAP reforms were effectively constrained by a very tight expenditure limit, agreed within the overall balanced budget. Section 7 concludes.

\section{2. $\quad$ The European Union Budget: Some Important Features}

The EUB has long been the source of much political debate and disagreement between the member states of the EU. Its political significance is, however, much greater than its size. In 1997 the EUB spent about ECU 79.3 billion, approximately $£ 54.9$ billion (see Court of Auditors, 1998). This compares with current national 
government expenditures of about ECU 467 billion in the UK, about ECU 838 billion in Germany and about ECU 3339 billion for the fifteen EU member states in total (all figures in current prices). EU expenditure represents about 1\% of EU GDP, whereas national general government current expenditures in 1997 ranged from about 32\% of national GDP in Ireland to over 61\% in Sweden, with an EU average (excluding Luxembourg) of 46.6\% (data from European Commission, 1998).

A second distinguishing feature of the EUB is that it has to be in balance each year. Although the EU has the ability to borrow funds through, for example, the European Investment Bank, it cannot use this facility to fund the general operational expenditures that are covered by the European Economic Community (EEC). There is, in short, no facility for deficit financing. This rule was broken in the mid 1980s and exceptional temporary measures were needed to allow the EU to continue funding its policies (this is discussed further below). The principle of the balanced budget has, however, generally been adhered to.

To complicate matters, EU expenditure can be classified in different ways, according to when the expenditure is due. It is a general operating rule of the EUB that it is proposed and agreed each year. Some EU policy expenditures, such as 'guarantee' expenditures under the Common Agricultural Policy (CAP) that support farm incomes, only apply to the year in question. Other policies, for example regional spending, involve multi-annual payments to particular projects. Thus in any one year there will be expenditures due from projects agreed in previous years, as well as expenditures due in future years on projects agreed in the current year. Where expenditures only apply to the year in question, such as CAP guarantees, they are known as non-differentiated appropriations. When payments are to be made over more than one year, the expenditures are known as differentiated appropriations. They 
are split into payment appropriations (where expenditures identified in the current year are also made in the current year) and commitment appropriations (which includes expenditures identified in the current year to be made in future years). From this, appropriations for payment are the total of non differentiated appropriations and payment appropriations from the current year, plus commitment appropriations from previous years where payment is due in the current year. The balanced budget rule is then applied to appropriations for payment. ${ }^{1}$

A further distinction between different expenditure items is rather more arbitrary, but nonetheless extremely important. Article 272 of the Treaty of Rome (previously Article 203), distinguishes between 'expenditure necessarily resulting from this Treaty or from acts adopted in accordance therewith' and 'expenditure other than that necessarily resulting from this Treaty or from acts adopted in accordance therewith' (this author's emphasis). The former is commonly known as compulsory expenditure and the latter as non-compulsory expenditure. The main element of compulsory expenditure is agricultural guarantee spending, although food aid measures, certain administrative costs and some monetary reserves are also classified as compulsory. Everything else is non-compulsory.

The origin of this distinction is the Luxembourg Treaty of 1970, which granted the Assembly (now the European Parliament) greater powers over the EUB. The ultimate decision making powers for non-compulsory expenditures were given to the Assembly, whereas for compulsory expenditures they were retained by the Council of Ministers. This has effectively constrained the degree of financial autonomy enjoyed by the Assembly/Parliament. The reason for this lies in how total expenditure under each type is determined. For compulsory expenditures, the essence is that once policies and policy goals have been determined within the Treaty (eg the 
objectives and policy instruments for agricultural guarantees under Article 33, previously Article 39), the EU is then obliged to spend as much as is necessary to fulfil those goals. With non-compulsory expenditures, however, the total sums available are limited and subject to a maximum rate of increase each year. In effect, for compulsory expenditures the policies are determined and the expenditure commitment is then open-ended, whereas for non-compulsory expenditures the spending limit is imposed and then the funds are allocated between competing claims.

One of the main problems that led to the Empty Chair Crisis in 1965 was the proposal to increase the budgetary powers of the Assembly in line with the EUB being granted its own resources, independent of the member states. Given the opposition of France to the transfer of powers away from the member states (through the Council) to the Assembly in 1965, it approved of the distinction made in the Luxembourg Treaty as it believed the arrangements placed an effective limit on the autonomy of the Assembly. Despite subsequent changes to the balance of power between institutions, the basic distinction remains and in terms of financial growth and political significance, the areas of activity over which Parliament has financial control have remained subordinate to those areas (principally CAP guarantees) controlled by the Council, even though non-compulsory expenditures have risen as a share of the EUB from about a fifth initially to about a half currently.

\section{The Rule of the Balanced Budget}

There is an extensive literature on the design and application of balanced budget rules (see, inter alia, Alesina and Perotti 1995, 1996; Corsetti and Roubini 1996; Poterba 1994, 1996; Robinson 1996). The principal focus of this literature is the application of the balanced budget rule to sub-national levels of government, in particular regions 
within (fiscal) federations. With sub-national governments, the application of the balanced budget rule is shown to contribute to fiscal restraint. Poterba (1996) suggests that differences between US state practices towards balanced budget rules and state fiscal outcomes in the US indicate those states that reduce spending to keep within short term budget limits also have lower levels of spending in the long term.

In terms of the main fiscal functions that can be allocated to budgets, it is typically the case that sub-national budgets undertake allocation and distribution roles. In contrast with national government budgets, however, typically they do not undertake stabilization. This distinction is important in terms of the balanced budget rule, insofar as this rule requires budgets to balance each year. By their nature, stabilization expenditures will fluctuate as the economy moves through the economic cycle and is hit by short term shocks. To impose a balanced budget rule on a budget with the stabilization function could require large year to year movements in revenues or, alternatively, constrain the effectiveness with which stabilization could be undertaken by limiting the finances available for stabilization.

In the case of the EUB the focus is not on sub-national budgets but on a supranational budget. The EUB can, however, be compared directly to sub-national budgets in that it too undertakes distribution and allocation, but does not have a role in economic stabilization - that function is still performed by national budgets. Thus the difficulties of trying to maintain budgetary balance in the face of cyclical stabilization expenditures are not encountered. A further factor supporting the imposition of the balanced budget rule to the EUB concerns political accountability. The EUB is further away from voters and the balanced budget rule is thus a means by which voters can be reassured that expenditures will not be allowed to rise without limit or effective control. Indeed, it was the wish of the authors of the Treaty of Rome 
"not....to offer the Communities, and in particular the Commission, any easy solutions” (Strasser 1992, page 57) in determining expenditures and revenues.

If stabilization would bring into question the appropriateness of applying a balanced budget rule, what can be said of the distribution function (under which heading spending on regional and structural measures and the CAP represent between $80 \%$ and $90 \%$ of total EUB outlays each year)? By definition, the growth in regional spending is limited each year since it is classified as non-compulsory expenditure and is thus determined by policy process rather than external economic factors subject to shocks. With the CAP, as will be seen further below, spending is determined by several factors but typically not economic cycles nor shocks to economies. In general, therefore, the principal expenditures undertaken by the EUB are not subject to the same fluctuations as stabilization and thus the balanced budget rule is not an inappropriate means of controlling EUB expenditures.

In contrast to most of the literature on balanced budget rules, Robinson (1996) argues against the use of the 'standard' balanced budget rule at the sub-national level. He suggests that rather than balancing the budget every year, what is needed is a policy of keeping stable the level of public goods provision. This includes lumpy capital expenditures, so balanced budget policies will lead to variations in tax levels to accommodate such expenditures. Thus he argues that deficits should be permitted to absorb variations in capital expenditures in particular. "The rule that budgets should be structurally balanced on an accrual basis, when coupled with some type of ceiling on debt/output, is probably the best formulation presently available” (page 60). The EUB, however, only undertakes current expenditures negotiated within an annual budget process and does not include capital expenditures. The narrowness of the range of economic functions undertaken by the EUB, in this case just current 
expenditures, therefore further supports the application of the balanced budget rule to the EUB.

4. Alesina \& Perotti and Balanced Budget Rules: The Paradox of the EU Budget Regarding the suitability of balanced budget rules, Alesina and Perotti (1996) caution against such rules on several grounds. These include the possibility of greater volatility in tax rates in order to match the movement of budget expenditures (as discussed above with stabilization expenditures), the danger that such strict rules “increase the incentives for creative and nontransparent accounting” (Alesina and Perotti op cit, page 402) and a concern that with multiyear financial plans, "the really tough policies are systematically postponed to year 2 , 3, or 4 of the plan and never implemented, since multiyear plans can be revised every year.” (ibid, page 403) The extent to which these concerns apply to the EUB are now considered.

Regarding fluctuations in spending, the EUB does not undertake stabilization and non-compulsory expenditures are subject to a ceiling on their annual rate of growth. Compulsory expenditures, essentially CAP guarantees, are discussed in more detail below. What volatility there has been in expenditures is linked more to climatic conditions (affecting supply) and the ECU:Dollar exchange rate than to the business cycle or economic shocks. Recent reforms have, moreover, changed the balance of CAP expenditures, placing a much greater emphasis on direct payments, independent even of these variables and should increase further the stability of CAP spending. This is illustrated below in Table 3 .

Transparency and creative accounting, as they apply to the EUB have, however, raised problems. Concerns have focused mainly on CAP spending, but there were problems with regional spending as well. The worst problems came to light 
during the mid 1980's. A report from the European Commission in 1987 opened with this frank assessment of the situation (EC Commission 1987, page 1):

The Community is at present faced with a budgetary situation which can only be described as being on the brink of bankruptcy. The unfolding of this situation should come as no surprise to the Community as it has developed gradually in the course of several years, and it has been announced with increasing disquiet by the Commission during this period. The background is, of course, complex, but some fundamental factors may be distinguished:

- First of all, the Community has sunk into a morass of budgetary malpractices needed to conceal or postpone the real financial implications of Community policies.

- Secondly, the own resources system itself has proved increasingly inadequate.

- Thirdly, the Community has not been equipped with the necessary means to adapt policies to the desired expenditure scenarios.

The central problem was the open-ended nature of compulsory expenditure. On the back of ineffective political constraint and inappropriate policy decisions regarding the CAP, agricultural expenditures grew until, in 1984 and 1985, total EUB spending rose through the own resources ceiling, requiring additional payments from member states in those two years simply to allow the EU to continue to function and fulfil its policy obligations. With the CAP, there was a simple short term means of postponing 
expenditures, given the EU was 'on the brink of bankruptcy'. As surpluses of various products rose, there were essentially two alternative outlets - export and intervention. Products sold for export received a subsidy equal to the difference between the internal EU price and the third country selling price. Alternatively, when products were sold into intervention, costs of storage had to be met, as did the difference between the intervention price and the third country selling price when the products were finally exported. The latter element is effectively the same as the export subsidy on open market sales, but is treated differently within the EUB.

The important difference between export and intervention came in the timing of the claim on the EUB for these costs. With exports from the open market, the EUB had to reimburse the exporter for the subsidy within weeks of export. With intervention, however, whilst the member states were reimbursed storage costs month by month the largest cost - that of the subsidy on export - could be delayed until the product was sold out of intervention. For cereals, this occurred on average two and a half years later (Ackrill 1992, page 5.26). In effect, intervention stocks were significantly over-valued, as the book value was recorded as the purchase price rather than the resale price. The result was a delay in expenditures incurred by the EUB, brought about by a delay in stock re-valuation until the goods were sold from intervention. Table 1 demonstrates the extent of the problem:

TABLE 1: Agricultural Stocks (end of year levels), billion ECU

\begin{tabular}{lcccccc}
\hline & 1982 & 1983 & 1984 & 1985 & 1986 & 1987 \\
\hline Value at: & & & & & & \\
Intervention Prices & 4.0 & 7.0 & 8.8 & 10.6 & 11.2 & 12.3 \\
Market Prices & 2.2 & 3.6 & 4.3 & 4.9 & 3.7 & 4.2 \\
Depreciation Required & $45 \%$ & $49 \%$ & $51 \%$ & $54 \%$ & $67 \%$ & $66 \%$ \\
\hline
\end{tabular}

Source: EC Commission, 1987, page 7. 
In addition, there were financial malpractices with the financing of certain regional projects, creating the "cost of the past". This referred to the problem whereby "heavy spending commitments had been built-up under the various structural funds and that these had not been matched by a corresponding pattern of spending: thus there is a major overhang of expenditure to be funded in future years.” (Swinbank 1988, pages 5-6. See also Swinbank 1986).

Table 2 summarises the total cost of this financial mismanagement. Up to 1985, the official limit on the VAT own resource contribution was $1.0 \%$ of the VAT base. In 1984, agreement at the Fontainebleau Summit led to this being increased to 1.4\% from 1986. Table 2 shows the extent to which additional payments were needed in 1984 and 1985 (in those years, the actual VAT rate applicable was still 1.0\%), as well as the increased VAT limit being used up in full in 1986, the first year the extra resources became available.

TABLE 2: Actual budget and true budget, as \% VAT rate required for financing

\begin{tabular}{lccccc}
\hline & 1983 & 1984 & 1985 & 1986 & 1987 \\
\hline Actual budget VAT rate & 1.00 & 1.14 & 1.23 & 1.40 & 1.39 \\
\hline non-budgeted expenditure: & - & - & - & 0.10 & 0.23 \\
current deficit ${ }^{1}$ & 0.13 & 0.08 & 0.08 & 0.10 & 0.03 \\
non-depreciation of agricultural stocks & 0.09 & 0.06 & 0.09 & - & - \\
"cost of the past” & 1.22 & 1.28 & 1.40 & 1.60 & 1.65 \\
\hline VAT rate needed for proper financing & 3.0 & 6.0 & 8.6 & 12.2 & 17.0 \\
\hline Accumulated liabilities (billion ECU) & & & & &
\end{tabular}


Alesina and Perotti's concerns that balanced budget rules "increase the incentives for creative and nontransparent accounting” are therefore seen to have had strong foundation in considering the EUB. The third problem they identify with balanced budget rules concerns multiyear financial plans, in particular a possible lack of transparency in the budget process that such an approach may generate. This could provide a means by which the budgetary authority could delay or avoid difficult policy decisions. Following the budget crisis of 1984 and 1985 and the full utilisation of budgetary resources in 1986 and 1987, a package of reforms was agreed in Brussels in February 1988 to both the CAP and the EUB. Given the concerns of Alesina and Perotti, it is interesting to note that an important part of the reforms involved the introduction of multiyear financial plans, the so-called 'financial perspectives'.

These plans, so far covering 1988-1992, 1993-1999 and 2000-2006 chart the growth of expenditure permitted on individual policies, but also give direction to broader policy aims. Thus spending on structural policies has been growing in absolute terms and as a percentage of total expenditures, whereas CAP spending has generally been growing in absolute terms, but falling as a percentage of total spending. Although the detailed budgetary decisions are still taken through the annual budget process, multiyear financial plans have helped increase the transparency of the budget process and clarified the limits within which each annual decision is taken.

The paradox of the concerns of Alesina and Perotti vis-a-vis the EUB lies in the way the EU responded to the financial crises of the mid 1980s. There was clearly financial mismanagement with the EUB at the time, but what brought that crisis to peoples' attention was the very presence of the balanced budget rule and the exhaustion of budgetary resources in 1984 and 1985. It can be argued that the 1988 
reforms, including the introduction of multiyear financial plans, have been instrumental in bringing stability to EU finances. One of these reform measures dealt directly with the problem of the "cost of the past". At the root of the problem was the failure to depreciate the value of stocks to reflect their resale value rather than purchase price. The 1988 reforms require that now, stocks must be fully depreciated and the EUB pay the member states this cost - by the end of the financial year in which they are purchased. Thus the EUB must bear the full financial cost of depreciation during the year of purchase, rather than delay this expenditure perhaps several years until stocks are re-sold. ${ }^{2}$ In addition, special financial provision was made to depreciate existing stocks, the cost of which was spread over the years 1988 to 1992.

Alesina and Perotti (1995, page 25) also suggest that balanced budget rules result in a "loss of flexibility in reacting to shocks on expenditure or revenues." Another reform introduced in 1988 has addressed this directly. Since 1988, the EUB has included a number of reserves that have been designed to deal with financial shocks. One of the main shocks to affect CAP expenditures is movements in the ECU:Dollar exchange rate affecting, for example, export subsidy expenditures by altering the dollar price of EU exports. If, compared with the initial budget, exchange rate movements result in expenditures being affected by at least 200 million ECU, then the 'Monetary Reserve' can be called into action, up to a maximum of 500 million ECU. ${ }^{3}$ This operates symmetrically, so that financial gains can be added to the reserve as well as extra costs being covered from the reserve. In 1993, following crises and upheaval in the Exchange Rate Mechanism, the reserve could also be drawn upon in cases where realignments within the European Monetary System pushed expenditures beyond the guideline. This reserve and others (see EC 
Commission 1995, pages 67 and 74-76), offer a degree of flexibility to the budget, whilst the cap on available funds helps ensure it does not significantly compromise the balanced budget rule. The rule of universality, whereby the EUB cannot ringfence monies for specific end-uses, is compromised but the sum is limited and the benefit is flexibility without financial mismanagement. Indeed, the negative reserve requires that additional expenditures in one or more policy areas are financed during the year from savings in other areas (EC Commission op cit, page 67).

A further budget reform in 1988 which helped bring stability to EU finances was the introduction of a new fourth own-resource, based on GNP. Previously, total own resources consisted of agricultural levies and tariff revenues, plus the VAT-based payment. From this total, member states were then reimbursed $10 \%$ to cover the costs of collecting the levies and tariff. Second, the rebate made to the UK for its inappropriately large net contribution had to be funded. By the mid 1980s, the effect of these two payments was to reduce the effective VAT rate from $1.4 \%$ to nearer $1.25 \%$, depriving the EU of funds for (non-compulsory) expenditures. The new system has traditional own resources paid over to the EU net of collection costs. Next, VAT is paid up to a limit, which has been reduced back to $1 \%$ from 1999 . The remaining own-resource requirements then come from GNP, up to a limit imposed not on this GNP resource but on total own resources. In other words, the GNP resource acts as a top-up payment, taking total own resources available for funding EU activities up to the limit, set at 1.27\% of EU GNP from 1999 and throughout the next financial perspective to 2006. In this way, neither the reimbursement of collection costs nor the UK rebate deprive the EUB of funds for the policies (effectively those whose expenditure is non-compulsory) set out in the financial perspective. 


\section{The Role of CAP Reform in Improving Budgetary Discipline}

The effect of the balanced budget rule has been to constrain growth in EUB spending and ensure it remains within revenue limits. It has been seen how, in response to the one time when this rule was broken, the EU introduced several important changes to the EU budgetary process, notably in 1988, to help ensure this did not happen again. In terms of expenditure growth, however, the limit imposed on the annual rate of growth of non-compulsory expenditures means that the only significant source of growth in expenditures that could threaten the balanced budget rule remains compulsory spending, principally CAP guarantees. Thus the focus of expenditure reforms to complement the reforms to the revenue side of the budget has been to reform the CAP.

1988 was the first time the two inter-related policies of CAP and budget underwent simultaneous reform. It has been shown, for example, how changes in the treatment of intervention expenditures improved financial management and control. Although the share of the EUB taken up by the CAP has been falling for several years, it still absorbs about $50 \%$ of total spending. In the past, there have been problems of both rising and unpredictable expenditures. Whilst the nature of agriculture is such that production uncertainties cannot be totally removed, a further reform to the CAP, agreed in 1992, made significant changes to the nature of support and hence to budgetary stability. In particular, support prices were reduced significantly and replaced with direct income support payments. This shifted the composition of CAP guarantee expenditures away from export subsidies and intervention storage, towards direct compensation. 
This switch makes expenditure less dependent on supply and the ECU:Dollar exchange rate. Expenditures such as export subsidies, that are dependent on exchange rates, are now much less significant in terms of total CAP spending, as Table 3 below shows. This reform was thus matched by the reduction in the funds made available through the monetary reserve, from 1000 million ECU to 500 million ECU. Compensation payments, now the dominant element of expenditure on the arable sector, are instead dependent on previous yields and current arable area and should thus be more stable. The other side of the reforms, however, is that CAP spending rose quite sharply. This is to be expected, as support has switched from consumers (through high support prices) to taxpayers (through compensation paid directly from the EUB). Whilst expenditures have risen as the nature of support has shifted from consumers to taxpayers, the benefit should be greater stability, as expenditures are determined more by area than by production, surpluses and exchange rates. Table 3 shows how, for the cereals sector, expenditure rose sharply during the period when the compensation payments were phased in (the 1993/4 to 1995/6 crop years), but has since become more stable. The recent rise in compensation payments and decline in set aside payments is related to the lowering of the set aside percentage required of large arable farmers.

There is, moreover, a further benefit to come from the reform transferring CAP expenditures towards direct payments for farmers. Previously, the total cost of the CAP was considerably greater than the budgetary expenditure figures suggested. This is because the bulk of support was hidden in the form of high prices faced by consumers. As prices faced by consumers fall towards world market levels, so the margin of support provided by consumers falls. ${ }^{4}$ Instead, support is provided by 
taxpayers and the cost is shown in the budget as budgetary expenditure. Thus this switch in the basis of support helps make the cost of the CAP much more transparent.

TABLE 3: Rising Spending on the Arable Sector with the 1992 Reforms

\begin{tabular}{|c|c|c|c|c|c|c|c|c|}
\hline \multicolumn{9}{|c|}{ Cereals/Arable Expenditure Data (million ECU) } \\
\hline year $(*=$ forecast $)$ & 1992 & 1993 & 1994 & 1995 & 1996 & 1997 & 1998* & $1999 *$ \\
\hline refunds & 3139.7 & 2788.8 & 1513.2 & 1092.7 & 312.8 & 532.3 & 397 & 877 \\
\hline Intervention Storage $^{1}$ & 2497.4 & 2723.8 & 186.7 & 62.7 & -46.5 & 71.5 & 186 & 650 \\
\hline Intervention, other than storage & 431.4 & 472.2 & 388.5 & 357.3 & 304.6 & 300.7 & 276 & 378 \\
\hline Co-Responsibility Levy & -1067.9 & 149.7 & & & & & & \\
\hline \multicolumn{9}{|l|}{ Compensation (small producers) } \\
\hline -total arable & 0 & 0 & 1756.4 & 2313.9 & 2875.6 & 2850 & 2596 & 2454 \\
\hline -of which, cereals & 0 & 0 & 1634.4 & 2257.1 & 2838.9 & 2808.3 & 2559 & 2404 \\
\hline \multicolumn{9}{|l|}{ Compensation (large producers) } \\
\hline -total arable & 0 & 3292.1 & 7083.5 & 8780.5 & 10660.4 & 11815.6 & 12397 & 12178 \\
\hline -of which, cereals & 0 & 425.9 & 3906 & 5909.6 & 7721.0 & 8796.4 & 9171 & 9363 \\
\hline Set Aside Compensation (new) & 0 & 0 & 1290.1 & 2162 & 2112.1 & 1827.8 & 1240 & 1294 \\
\hline Total Set Aside & 285.6 & 426.8 & 1712.9 & 2412.6 & 2271.4 & 1903.6 & 1250 & 1294 \\
\hline Total Cereals ${ }^{2}$ & 5742.5 & 6987.1 & 9340.8 & 12090.6 & 13495.2 & 14412.8 & 13839 & 14966 \\
\hline Total Arable & 10356.2 & 10610.7 & 12652.3 & 15018.3 & 16372.3 & 17462.1 & 17102 & 17831 \\
\hline Total FEOGA Guara & 31369.4 & 34590.4 & 32970.4 & 34502.7 & 39107.8 & 40674.9 & 40737 & 40735 \\
\hline
\end{tabular}

Source: EU budgets, in Official Journals L34 1994, L369 1994, L22 1996, L44 1997, L44 1998 and L39 1999.

Notes: 1: The negative figure for 1996 reflects large over-devaluation of intervention stocks, as discussed in the text. At this time, world prices rose to exceptionally high (and clearly unforeseen) levels.

2: Cereals includes all set aside payments as these are not differentiated by product.

\section{The 1999 CAP Reform: A Case of the Budget Constraining the CAP}

In preparation for the future enlargement of the $\mathrm{EU}$, the national leaders at their summit in Berlin in March 1999 reached agreement on the financial perspective for the period 2000 to 2006, as well as reforms to regional policy and the CAP. In this section, certain key features of the CAP reform agreement will be outlined (a fuller analysis can be found in Ackrill 1999a, 1999b). It will be argued that this reform provides an outstanding example of how the limits imposed by the budget constrained 
what was possible for the CAP. This will show how important the financial perspective, in conjunction with the balanced budget rule, has become in ensuring financial discipline in the EU, in contrast to the fears of Alesina and Perotti.

Table 4 summarises some of the key elements of the financial perspective agreed at Berlin. The original proposed spending limit on CAP guarantees, set down in the Agenda 2000 documents, was euro 312.5 billion over the period to 2006. At the Petersberg meeting of the European Council in late February 1999, however, a lower figure was agreed, of euro 40.5 billion per year or euro 283.5 billion over the full period of the agreement. Allowing spending to rise in line with inflation, assumed at 2\% a year, gives total real spending of euro 307.1 billion over the period to 2006 . This figure became known as 'stabilized' expenditure and became the constraint that was placed on those negotiating the CAP reform.

TABLE 4: Elements of the Financial Perspective, 2000-2006 (EU 15, 1999 prices, million euro, unless otherwise stated)

\begin{tabular}{lrrrrrrr}
\hline Item & $\mathbf{2 0 0 0}$ & $\mathbf{2 0 0 1}$ & $\mathbf{2 0 0 2}$ & $\mathbf{2 0 0 3}$ & $\mathbf{2 0 0 4}$ & $\mathbf{2 0 0 5}$ & $\mathbf{2 0 0 6}$ \\
\hline Agriculture & 40920 & 42800 & 43900 & 43770 & 42760 & 41930 & 41660 \\
- CAP guarantees & 36620 & 38480 & 39570 & 39430 & 38410 & 37570 & 37290 \\
- rural development, other measures & 4300 & 4320 & 4330 & 4340 & 4350 & 4360 & 4370 \\
Structural Operations & 32045 & 31455 & 30865 & 30285 & 29595 & 29595 & 29170 \\
Pre-Accession Aid & 3120 & 3120 & 3120 & 3120 & 3120 & 3120 & 3120 \\
Total Payment Appropriations & 89600 & 91110 & 94220 & 94880 & 91910 & 90160 & 89620 \\
-as \%GNP & 1.13 & 1.12 & 1.13 & 1.11 & 1.05 & 1.00 & 0.97 \\
Available for Accession & & & 4140 & 6710 & 8890 & 11440 & 14220 \\
Ceiling on Payment Appropriations & 89600 & 91110 & 98360 & 101590 & 100800 & 101600 & 103840 \\
- as \%GNP & 1.13 & 1.12 & 1.18 & 1.19 & 1.15 & 1.13 & 1.13 \\
Total Own Resources, \%GNP & 1.27 & 1.27 & 1.27 & 1.27 & 1.27 & 1.27 & 1.27 \\
\hline
\end{tabular}

Source: European Parliament, Council, Commission. Interinstitutional Agreement on Budgetary Discipline and Improvement of the Budgetary Procedure. Official Journal of the European Communities C172, 18.6.1999, pp. 1-22. 
In mid-March 1999, the Ministers of Agriculture negotiated a reform of the CAP. Two problems arose with this, however. The first was that France refused to accept that a reform had indeed been agreed. According to Jean Glavany, the French minister, 'notable advances' had been made in the discussions, but argued that the 'decision' had instead been an informal qualified majority-based vote, based on the negotiating positions of the national delegations. Whilst every other country believed an agreement had been concluded, France was adamant this was not the case. This concern notwithstanding, this reform 'agreement' would still have caused difficulties because it broke the budget expenditure limit agreed the previous month. Joschka Fischer, the German foreign minister, estimated the reform would cost euro 289.3 billion. EU foreign ministers indicated they would need to 'fine-tune' the deal in order to reduce spending to the agreed limit, but did not intend to alter the basic features of the reform. The European Commission, on the other hand, noted that the agreed deal had raised spending by only $2 \%$ above the target figure and felt that further changes were ‘unlikely'.

In the end the CAP underwent further reform just two weeks later at the hands of the European Council at the Berlin summit. The basic direction of reform in the first agreement ${ }^{5}$ was to continue the pattern established in 1992, whereby support prices were cut and offset, at least in part, by direct payments. The first agreement established a cut in cereals prices of $20 \%$, to be phased in over two years. Over that period, set aside would be retained and set at $10 \%$. Once the full price cut had been implemented, set aside would normally be set at zero. The main change from the first to the second agreements was to retain the basic element of compensated price cuts, but to reduce the price cut to $15 \%$. This would reduce the cost of the direct payments to farmers from the EUB by making them commensurately smaller. ${ }^{6}$ 
Given, in particular, French opposition to significant change to the CAP and the desire of other countries to limit the rise in spending, these further changes made to the arable sector from the first to the second agreements raise several issues. Although the basic nature of reform remained intact, the smaller price cut will have certain important consequences. The first is that by making the price cut smaller, the level of cereals compensation is also made smaller, thus reducing the cost of the direct payments. In addition, oilseeds payments are to be cut to the same level as those for cereals. Given the smaller rise in cereals payments, the cut in oilseeds payments will need to be larger, thus again saving money. This was the aim in trying to adapt the reform to respect the ‘stabilized' spending limit. The second consequence of the adjustments made in Berlin is that the internal European market price is expected, under normal world market conditions, to remain above the world price (according to OECD estimates). This implies export subsidies will be retained and, therefore, that an element of expenditure will continue to be subject to the vagaries of exchange rates. Despite this, between 2001 and 2003 the Monetary Reserve is to be phased out. This could mean that expenditures on export subsidies become more volatile as exchange rate impacts are no longer dampened by the reserve.

Moreover, given that export subsidies are to be retained, EU exports will continue to be subject to the constraints imposed as part of the 1994 Uruguay Round Agreement under the General Agreement on Tariffs and Trade (GATT). By imposing a limit on the volume of exports that can be exported with the aid of subsidies, additional quantities will either need to be sold without subsidy or sold into intervention, precipitating a possible return to the problems of the mid 1980s. Thus whilst the second agreement ensured that the rise in expenditure on direct payments was restricted, a rise in subsidy and intervention expenditures is now a distinct 
possibility. Moreover, under the second agreement set aside is to be retained at $10 \%$ to help restrain production and thus the size of the surplus. This is in contrast to the first agreement, when a price cut of $20 \%$ would lead to set aside normally set at zero. Indeed German Chancellor Gerhard Schröder felt the final agreement will lead to spending still rising above the agreed limit. Moreover Günther Verheugen, then German deputy foreign minister, conceded further reforms of the CAP would be needed before 2006 .

These problems were created by the short-term nature of the budgetary savings agreed at Berlin, made through a partial reversal of the first agreement reforms. With an inherent conflict between simply replacing price support with direct payments and controlling the rise in budget costs, what alternatives were available? During the negotiations on CAP reform, several alternatives were considered but none could be agreed upon. Given the rise in budget costs consequent on the $20 \%$ price cut, each proposed alternative ways of dealing with this rise. These were modulation (limiting payments to certain classes of farm, principally the largest farms that receive most payments), co-financing (the sharing of the budgetary burden of the CAP between the EUB and national budgets) and degressivity (the gradual reduction in the size of the direct payments over time).

Co-financing reduces the cost of CAP support borne by the EUB, but does not reduce the overall cost of the policy. The 1999 reform agreement has introduced 'national envelopes' for beef and dairy production. This allocates budget sums to national governments to distribute according to particular national or regional priorities. This is not the same as co-financing as it is an additional sum, although it does allow national governments to direct some support towards smaller farmers if they so choose. Nor does it limit the sums available under the general policy to large 
farmers and thus is not a serious attempt at introducing modulation. Moreover, the total sum available (just over euro 1.4 billion from 2002) represents just 3.5\% of total expected CAP guarantee spending in that year.

Degressivity, supported by several countries, offers perhaps the best long term option for expenditure control. The extent of the savings, however, depends on the exact implementation of the policy. At the extreme, payments could be reduced to zero over a fixed time period. Less radical alternatives put forward during negotiations included a proposal from France to reduce payments by 1-3\% a year with exemptions for small farmers (thus also incorporating an element of modulation). The UK proposal was for $4 \%$ cuts across the board (given its higher percentage of large farmers, the UK has always opposed modulation). Estimates indicate cuts of $3 \%$ a year across all payments could save about euro 4.6 billion over seven years, whilst cuts of $3 \%$ a year to arable payments and $1 \%$ a year for other sectors would save about euro 3.1 billion.

This debate shows one potential problem of the balanced budget rule in the context of CAP reform. The imposition of a tight limit on CAP spending by the European Council led to the need for the second agreement. In terms of reaching an agreement that reduced spending, however, the alternatives were essentially to choose one (or more) of three options that would have controlled spending in a sustainable way over the longer term, or reducing the budgetary consequences of the price cuts simply by moderating them and so reducing the size of the direct payments. The latter was the easier politically, as it represents a continuation of existing policy, despite only being a short term palliative, whereas any one of the other three options represents a new direction for the CAP. The second agreement, moreover, implies a constraint on 'new' expenditures (direct payments), but renewed growth in 
'traditional' expenditures (subsidies and intervention). Thus the response to the spending limit was to take the arable reform from the first agreement, remove the element that was a genuine step forward (eliminating price support under normal market conditions and, hence, the need for set aside to help limit production), instead rendering the 'reform' simply a small movement forward from the position agreed in 1992. Moreover, the main change between the first and second agreements for the dairy sector was to delay the introduction of the measures until 2005/06. This will maintain the status quo for longer, delaying the introduction of direct payments, but also slowing down the restructuring of the dairy industry.

What this also shows is that whilst the balanced budget rule is a de-politicised, rule-based policy, there is still enormous scope for political debate in determining how a particular spending limit is to be achieved. France, as the least reform-minded country, wished to limit the scope of reform and managed to slow down the reform process to their pace. The European Council were faced with a simple option to water-down the first agreement reform package, or go for a more radical solution. The second agreement represented minimal change, which was desired by France, whilst also helping to contain budget costs, which was the desire of other countries, even if the second agreement may well not have contained costs sufficiently (see below).

France was, however, assisted in this debate by external factors. Events in Kosovo were proving a distraction and the EU needed to demonstrate it could put on a united front. The Commission had just resigned and the German government, in the chair, was facing domestic political difficulties. Failure to agree a reform would have further undermined the credibility of the EU. The debate was thus fundamentally between France (in opposing significant reform) and Germany (in the chair). Ackrill (1999b) refers to the 'arm-wrestling' between these two countries, who were aware 
also of the importance of the Franco-German axis at a time when these other pressures were affecting the credibility and image of the EU. The budget and the balanced budget rule played a key role in forcing CAP reform, but there was still plenty of scope for political debate over how the spending limit was to be respected.

The 1999 reform also highlights a subtly changing characteristic of compulsory expenditures. The basic idea that such spending is open-ended remains true. The balanced budget rule, allied with the financial perspectives have, however, improved the transparency and accountability aspects of the budgetary process to the point that the process of CAP reform was, for the first time in 1999, discussed in the context of an explicit limit on budgetary expenditures. The reform is not a long term solution and was politically the less difficult option to agree upon. Even so, the increased influence of the EUB on sectoral policies, most notably the 'compulsory expenditures' of CAP guarantees, is increasing, in the wider context of public sector fiscal restraint.

This could already be seen in the process of negotiations for the 2000 budget. Cutbacks in payments to sugar and dairy producers were agreed in order to respect the spending limit for 2000 and remove an expected overshoot of about euro 180 million. Moreover, reductions have been proposed to subsidies applied to processed products containing CAP-supported commodities, such as biscuits and spirits. This is the first clear sign that the 'new' approach to financial restraint, where the CAP has to respect a pre-determined spending limit, is starting to take effect. Whilst this does not strictly change the fundamental nature of compulsory spending, the fact that the policy instruments are being adjusted to ensure respect of the spending limit year by year does indicate a change in attitude towards the open-ended nature of such spending. 
Policy instruments are now being amended with specific reference to the spending limit.

\section{Conclusions}

The literature on balanced budget rules has supported the use of this rule for subnational governments, whilst broadly opposing its application to national government budgets. Little or no attention has so far been paid to the application of this rule to supra-national government budgets. Taking the specific case of the European Union budget, it has been argued that the application of the balanced budget rule has been entirely appropriate. Despite concerns over the possible problems this rule can generate, in the EU it has not only been suggested these concerns are unfounded, but indeed that the balanced budget rule has helped develop a system of sound financial management by highlighting the consequences of poor financial management.

Within the EU, expenditures are distinguished as being compulsory or noncompulsory. Given the institutional constraints imposed on the permitted growth of non-compulsory expenditures, the balanced budget rule has the greatest impact on compulsory expenditures, principally CAP guarantees. Financial and accounting mismanagement in the 1980s were made visible by the existence of the balanced budget rule. This forced reforms to the budgetary process that improved both financial management and transparency. Continued growth in CAP expenditures, however, led to financial crisis for the EU in the mid 1980s. This resulted in CAP reforms driven, in most cases, by a need to respect the limits imposed on CAP spending and the budget generally. The most extreme example of this was the 1999 reform of the CAP where, for the first time, an expenditure limit was stated explicitly to which those negotiating the reform of the CAP had to adhere. 
Balanced budget rules imply a de-politicised decision making process. The reality has been that whilst CAP reforms have tended to coincide with times of budget crisis, there is nothing in the balanced budget rule to say how the CAP should be reformed. Political debate and compromise is still critical in determining the shape of CAP reforms, therefore. The CAP reform of 1999 led to such a degree of compromise that, in negotiating the EUB for 2000, adjustments have already had to be made. Further reform will therefore be needed if the spending limit is to be respected through to 2006.

Plus ça change.

\section{REFERENCES}

Ackrill, Robert W. (1992) The EC Budget and Agricultural Policy Reforms, with Special Reference to Cereals. Unpublished $\mathrm{PhD}$ Thesis, University of Nottingham.

Ackrill, Robert W. (1999a) CAP Reform 1999: Crisis Management in Search of a Crisis? Discussion Papers in European Economic Studies No. 99/01, Department of Economics, University of Leicester.

Ackrill, Robert W. (1999b) Les Quinze á Table: Le Grand Marchandage. Courrier de la Planète, 51, 16-18.

Alesina, Alberto and Roberto Perotti (1995) The Political Economy of Budget Deficits. IMF Staff Papers, 42, 1, 1-31.

Alesina, Alberto and Roberto Perotti (1996) Fiscal Discipline and the Budget Process. American Economic Review, 86, 2, 401-407. 
Corsetti, Giancarlo and Nouriel Roubini (1996) European versus American Perspectives on Balanced-Budget Rules. American Economic Review, 86, 2, 408-413.

Court of Auditors (1998) Annual Report Concerning the Financial Year 1997. Official Journal of the European Communities. C349. Luxembourg: Office for Official Publications of the European Communities.

EC Commission (1987) Report by the Commission to the Council and Parliament on the Financing of the Community Budget. COM(87)101 Brussels: EC Commission.

EC Commission (1995) European Union Public Finance. Luxembourg: Office for Official Publications of the European Communities.

European Commission (1998) European Economy 66. Luxembourg: Office for Official Publications of the European Communities.

Poterba, James M. (1994) State Responses to Fiscal Crises: The Effects of Budgetary Institutions and Politics. Journal of Political Economy, 102, 4, 799-821.

Poterba, James M. (1996) Budget Institutions and Fiscal Policy in the U. S. States. American Economic Review, 86, 2, 395-400.

Robinson, Marc (1996) The Case Against Balanced Budgets. Australian Journal of Public Administration, 55, 1, 48-62.

Strasser, Daniel (1992) The Finances of Europe. 7th ed. Luxembourg: Office for Official Publications of the European Communities.

Swinbank, Alan (1986) Cogitations on the CAP. Discussion Paper No. 86/3, Department of Agricultural Economics and Management, University of Reading. 
Swinbank, Alan (1988) Can the EEC Reform the Common Agricultural Policy? Papers de Treball No. 4, Institut Valencià d'Economia. 


\section{NOTES}

${ }^{1}$ In addition, there are also appropriations for commitment. These do not equal own resources in any given year. They are, for any year, total non-differentiated appropriations plus commitment appropriations decided in that year and thus include expenditures to be met by budgets in future years.

${ }^{2}$ This depreciation is based on expected future re-sale value. Subsequent movements in market prices or exchange rates may mean stocks are over-depreciated, in which case member states reimburse the EUB the excess on re-sale.

${ }^{3}$ These limits have applied since 1995 . Previously, the monetary reserve was triggered by exchange rate movements altering expenditures by at least 400 million ECU, up to a limit of 1000 million ECU.

${ }^{4}$ In this context, 'consumers' refers to those who first buy the product of farmers. This is not people in shops, but those who buy from the farmer before storing, transporting, processing and packaging the food before it reaches final consumers. These 'first buyers' pay less to farmers under the new policy. The effect of this on 'final consumers' in the shops is limited by the extent to which the price paid for food includes elements of the marketing margin - the processing, storage, transport and other costs that come between the farmer and the shopper.

${ }^{5}$ For simplicity, the outcome of the meeting of Ministers of Agriculture will be referred to as the first agreement and that of the European Council as the second agreement, the views of France notwithstanding.

${ }^{6}$ The beef regime was left relatively untouched by the second agreement. In the dairy sector, the reforms were broadly accepted, but the introduction of the changes would be delayed from 2003/04 to 2005/06. In terms of the budgetary impact of the CAP reforms, the arable regime is of most interest and is thus the focus of attention here. 